Biochimica et Biophysica Acta, 374 (1974) 187-196

(c) Elsevier Scientific Publishing Company, Amsterdam - Printed in The Netherlands

BBA 98152

\title{
THE ATTACHMENT OF POLYRIBOSOMES TO MEMBRANES OF THE HYPOCOTYL OF PHASEOLUS VULGARIS
}

\author{
B. DOBBERSTEIN, D. VOLKMANN and D. KLÄMBT \\ Botanisches Institut der Universität Bonn, Meckenheimer Allee 170 D 53 Bonn (G.F.R.) \\ (Received June 17th, 1974)
}

\section{Summary}

Microsomal membranes were isolated from the rapid growing part of hypocotyls of Phaseolus vulgaris var. Saxa. The type of ribosome-membrane interaction was determined using EDTA, puromycin and ribonuclease. EDTA treatment $(3-5 \mathrm{mM})$ effected the preferential release of the small over the large ribosomal subunits from the membranes. Incubation of microsomes in puromycin at low and high $\mathrm{KCl}$ concentration revealed that ribosomes are attached to the membranes by the growing peptide chain and/or electrostatic linkage. Mild ribonuclease digestion released only about $10 \%$ of the membrane-bound ribosomes. Ribosome-membrane interaction in the hypocotyl of Phaseolus vulgaris resembles more that found in rat liver cells than that in cultured cells.

\section{Introduction}

In almost all animal and plant cells a certain number of ribosomes, varying greatly from one type of cell to another, is attached to cellular membranes $[1,2]$. It has been noted, that mammalian cells, active in the synthesis of secretory proteins, contain a large portion of membrane-bound ribosomes [3-5], whereas cells, synthesizing proteins primarily for intracellular use, have most of their ribosomes in the free state $[6,7]$.

Aleurone cells producing and secreting amylase show an increased synthesis of ribosomes [8] and endoplasmic reticulum membranes [9]. This suggests that also in plant cells membrane-bound ribosomes might be engaged in the synthesis of secretory proteins. The ubiquity of ribosome-membrane interaction in cells without obvious secretory function point to a more general significance [1]. Recently a number of reports have provided evidences that bound ribosomes synthesize membrane proteins $[10,11]$. Time-course analysis

Abbreviations: Tris- $\mathrm{KCl}-5 \mathrm{mM} \mathrm{MgCl} 2,50 \mathrm{mM}$ Tris- $\mathrm{HCl}, \mathrm{pH} 7.8$ at $2{ }^{\circ} \mathrm{C}, 50 \mathrm{mM} \mathrm{KCl}$ and $5 \mathrm{mM}$ $\mathrm{MgCl}_{2}$; Tris- $\mathrm{KCl}-2 \mathrm{mM} \mathrm{MgCl}$, $50 \mathrm{mM}$ Tris- $\mathrm{HCl}, \mathrm{pH} 7.8$ at $2^{\circ} \mathrm{C}, 50 \mathrm{mM} \mathrm{KCl}$ and $2 \mathrm{mM} \mathrm{MgCl}_{2}$. 
of some growth and developmental systems showed that the enhancement of the rate of membrane phospholipid synthesis coincides with rather abrupt increase in ribosomes, especially in the rough endoplasmic reticulum $[12,13,1]$.

The upper part of the hypocotyl of Phaseolus vulgaris is rapidly growing, depending on the action of growth hormone. Because the cell wall lies outside the plasma membrane one might expect enzymes involved in cell wall metabolism to be associated with membranes [14]. Cellulase activity could be shown to be associated with the microsomal fraction [15] and the synthesis of cell wall polysaccharides appears to be a membrane-related activity [16]. The experiments described in this report characterize the membrane-ribosome interaction in bean stem tissue.

\section{Materials and Methods}

Seeds of $P$. vulgaris var. Saxa were surface-sterilized for $10 \mathrm{~min}$ in $1 \%$ $\mathrm{NaClO}$. They were then rinsed several times in sterile water, imbibed for $8 \mathrm{~h}$, implanted in moist sterile vermiculite/sand $1: 1$ and grown in darkness at $27^{\circ} \mathrm{C}$ for $90 \mathrm{~h}$. After this time, when the hypocyl was 5-6 cm long, $20-\mathrm{mm}$ sections just below the cotyledons were excised and put into ice-cold water. All subsequent operations were performed at $2^{\circ} \mathrm{C}$. For the preparation of free and membrane-bound ribosomes a modified method of Blobel and Potter [3] and Redman [6] was employed. All results in this paper refer to $7 \mathrm{~g}$ tissue equivalent of ribosomes and microsomes.

\section{Preparation of free ribosomes and microsomes}

$7 \mathrm{~g}$ of hypocotyl sections were homogenized in a mortar in $20 \mathrm{ml}$ of grinding buffer $\left(0.25 \mathrm{M}\right.$ sucrose, $0.1 \mathrm{M}$ Tris- $\mathrm{HCl}, \mathrm{pH} 8.0$ at $2^{\circ} \mathrm{C} 50 \mathrm{mM} \mathrm{KCl}$ and $5 \mathrm{mM} \mathrm{MgCl}_{2}$ ). The resulting homogenate was filtered through three layers of cheesecloth and centrifuged at $1000 \times \mathrm{g}$ for $10 \mathrm{~min}$. The supernatant was centrifuged for $15 \mathrm{~min}$ at $10000 \times g$ and the resulting postmitochondrial supernatant layered on a discontinuous sucrose gradient with $4 \mathrm{ml} 1.4 \mathrm{M}$ over 4 $\mathrm{ml} 2 \mathrm{M}$ sucrose in Tris- $\mathrm{KCl}-5 \mathrm{mM} \mathrm{MgCl}_{2}$ buffer $(50 \mathrm{mM}$ Tris- $\mathrm{HCl}, \mathrm{pH} 7.8$ at $2^{\circ} \mathrm{C}, 50 \mathrm{mM} \mathrm{KCl}$ and $5 \mathrm{mM} \mathrm{MgCl}_{2}$ ) and centrifuged at $105000 \times \mathrm{g}$ for $17 \mathrm{~h}$. The pellet which sedimented through the $2 \mathrm{M}$ sucrose was designated as free polyribosomes. They were resuspended in Tris- $\mathrm{KCl}-2 \mathrm{mM} \mathrm{MgCl}_{2}$ buffer $(50$ $\mathrm{mM}$ Tris- $\mathrm{HCl}$, pH 7.8 at $2^{\circ} \mathrm{C}, 50 \mathrm{mM} \mathrm{KCl,} 2 \mathrm{mM} \mathrm{MgCl}_{2}$ ) and characterized in an isokinetic sucrose gradient $[17,18]$.

For the preparation of microsomes the material which sedimented at the interphase of $2 \mathrm{M}-1.4 \mathrm{M}$ sucrose was removed with a Pasteur pipette. It was diluted with Tris- $\mathrm{KCl}-2 \mathrm{mM} \mathrm{MgCl}_{2}$ buffer to give a final sucrose concentration of approx. $0.25 \mathrm{M}$ and centrifuged for $30 \mathrm{~min}$ at $105000 \times \mathrm{g}$. The resulting microsomal pellet was resuspended in Tris $-\mathrm{KCl}-2 \mathrm{mM} \mathrm{MgCl} \mathrm{m}_{2}$ buffer using a motor-driven Teflon pestle fitting the plastic tube of the centrifuge. After centrifugation for $30 \mathrm{~min}$ at $10000 \times \mathrm{g}$ the resulting pellet, denoted as washed microsomes, was resuspended in Tris- $\mathrm{KCl}-2 \mathrm{mM} \mathrm{MgCl}{ }_{2}$ buffer.

\section{Preparation of membrane-bound ribosomes}

$10 \%$ Triton X-100 was added to washed microsomes to give a final con- 
centration of $2 \%$. After $1 \mathrm{~h}$ standing in an ice bath, the mixture was centrifuged for $15 \mathrm{~min}$ at $10000 \times \mathrm{g}$ and the supernatant characterized in an isokinetic sucrose gradient. Purified membrane-bound ribosomes were prepared by layering the microsome-Triton X-100 mixture onto a discontinuous $2 \mathrm{M}-1.4 \mathrm{M}$ sucrose gradient, centrifuging for $17 \mathrm{~h}$ at $105000 \times \mathrm{g}$ characterizing the resulting pellet in an isokinetic sucrose gradient.

\section{Treatment of microsomes with EDTA [21]}

To washed microsomes, resuspended in $0.5 \mathrm{ml}$ of Tris- $\mathrm{KCl}-2 \mathrm{mM} \mathrm{MgCl}$ buffer, $100 \mathrm{mM}$ EDTA (pH 7.8 with $\mathrm{KOH}$ ) in Tris-KCl-2 $\mathrm{mM} \mathrm{MgCl}_{2}$ buffer was added to give the final concentrations of 3 (5 or 40) mM EDTA. The mixture was brought to $1 \mathrm{ml}$ with Tris- $\mathrm{KCl}-2 \mathrm{mM} \mathrm{MgCl}_{2}$ buffer and after $1 \mathrm{~h}$ centrifuged for $30 \mathrm{~min}$ at $10000 \times \mathrm{g}$. The supernatant was layered onto a 5-20\% linear sucrose gradient made in $50 \mathrm{mM}$ Tris $-\mathrm{HCl}, \mathrm{pH} 7.8$ and $50 \mathrm{mM}$ $\mathrm{KCl}$ and centrifuged for $12 \mathrm{~h}$ at $25000 \mathrm{rev} . / \mathrm{min}$ in an SW 25 rotor of a Spinco L 50 centrifuge.

\section{High salt-puromycin treatment [19]}

The reaction mixture contained washed microsomes in $0.5 \mathrm{ml}$ Tris$\mathrm{KCl}-2 \mathrm{mM} \mathrm{MgCl}_{2}$ buffer, $0.1 \mathrm{ml}$ of $5 \mathrm{mM}$ puromycin $\mathrm{pH} 7.5$ and $0.4 \mathrm{ml}$ compensating buffer to give a final concentration of $50 \mathrm{mM}$ Tris $-\mathrm{HCl}, \mathrm{pH} 7.8$, $50(500) \mathrm{mM} \mathrm{KCl}$ and $2 \mathrm{mM} \mathrm{MgCl}$. It was incubated at $37^{\circ} \mathrm{C}$ for $10 \mathrm{~min}$, cooled and centrifuged for $30 \mathrm{~min}$ at $10000 \times \mathrm{g}$. The supernatant was layered onto an isokinetic sucrose gradient made in $50 \mathrm{mM}$ Tris- $\mathrm{HCl}, \mathrm{pH} \mathrm{7.8,500} \mathrm{mM}$ $\mathrm{KCl}$ and $2 \mathrm{mM} \mathrm{MgCl}_{2}$.

\section{Ribonuclease treatment}

To washed microsomes, resuspended in $0.5 \mathrm{ml}$ of Tris- $\mathrm{KCl}-2 \mathrm{mM} \mathrm{MgCl}{ }_{2}$ buffer $5 \mu \mathrm{l}(2 \mathrm{mg} / \mathrm{ml})$ of pancreatic ribonuclease $(40$ units $/ \mathrm{mg})$ and Tris$\mathrm{KCl}-2 \mathrm{mM} \mathrm{MgCl}{ }_{2}$ buffer was added to give a final volume of $1 \mathrm{ml}$. After $0.5,1$ and $5 \mathrm{~min}$ of incubation at $37^{\circ} \mathrm{C}$ the mixture was cooled, centrifuged for 30 $\min$ at $10000 \times g$ and the supernatant layered onto an isokinetic gradient made in Tris- $\mathrm{KCl}-2 \mathrm{mM} \mathrm{MgCl} 2 \mathrm{MgCl}_{2}$ buffer.

\section{Sucrose density gradient analysis}

Isokinetic sucrose gradients $(25 \mathrm{ml})$ were calculated for a $D_{\mathrm{p}}=1.4$ and a sucrose concentration at the top of the gradient of $15 \%[17,18]$. Linear and isokinetic gradients were centrifuged at $25000 \mathrm{rev}$./min in the SW 25 rotor of a Spinco L 50 centrifuge. Temperature and duration of the centrifugation are indicated in the legends of the figures. The gradients were analysed by monitoring the absorbance at $254 \mathrm{~nm}$ in an LKB-Uvicord.

\section{Electron microscopy}

Mitochondrial fractions and microsomes were pelleted and fixed for $1 \mathrm{~h}$ in equal parts of ice-cold solutions of glutaraldehyde $(2 \%)$ and $\mathrm{OsO}_{4}(2 \%)$ buffered with $0.1 \mathrm{M}$ cacodylate [20]. After washing in cold $0.1 \mathrm{M}$ cacodylate buffer, the samples were postfixed in $\mathrm{OsO}_{4}(2 \%)$ buffered with $0.1 \mathrm{M}$ cacodylate for $1 \mathrm{~h}$ at $5^{\circ} \mathrm{C}$. After a washing step in $0.1 \mathrm{M}$ cacodylate at $5^{\circ} \mathrm{C}$ for 
approx. $1 \mathrm{~h}$, dehydration followed in increasing aceton concentrations $(15-100 \%)$. During this procedure temperature was allowed to rise slowly up to $25^{\circ} \mathrm{C}$. Embedding followed in Spurr's ERL. Thin sections cut on Reichert microtome were poststained with lead citrate.

\section{Results}

For the preparation of free and membrane-bound polyribosomes mitochondria had to be separated from the ribosomes and membranes of the endoplasmic reticulum. Centrifugation at $10000 \times \mathrm{g}$ for $15 \mathrm{~min}$ was found to be suitable for separating the mitochondria from very large polyribosomes and membranes. When the mitochondrial fraction was sedimented at larger centrifugal forces, it contained large portions of polyribosomes and rough membranes (Fig. 1). Fig. 2 is a representative electron micrograph of rough membranes collected onto the $2 \mathrm{M}$ sucrose layer after centrifugation of the postmitochondrial supernatant at $105000 \times g$ for $17 \mathrm{~h}$. No mitochondria were present in this fraction.

About $75-80 \%$ of the cytoplasmic ribosomes in the examined bean stem tissue were found to be in a free state. The rest was attached to membranes. This was calculated from the $260 \mathrm{~nm}$ absorbing material in the gradients of free and membrane-bound ribosomes (Figs $3 \mathrm{a}$ and $3 \mathrm{~b}$ ).

The $A_{260 \mathrm{~nm}} / A_{280 \mathrm{~nm}}$ ratio of free and purified membrane-bound ribosomes was $1.75-1.8$, that of membrane bound ribosomes $1.65-1.7$. A value of 1.7 is generally considered to be indicative of a highly purified polyribosome

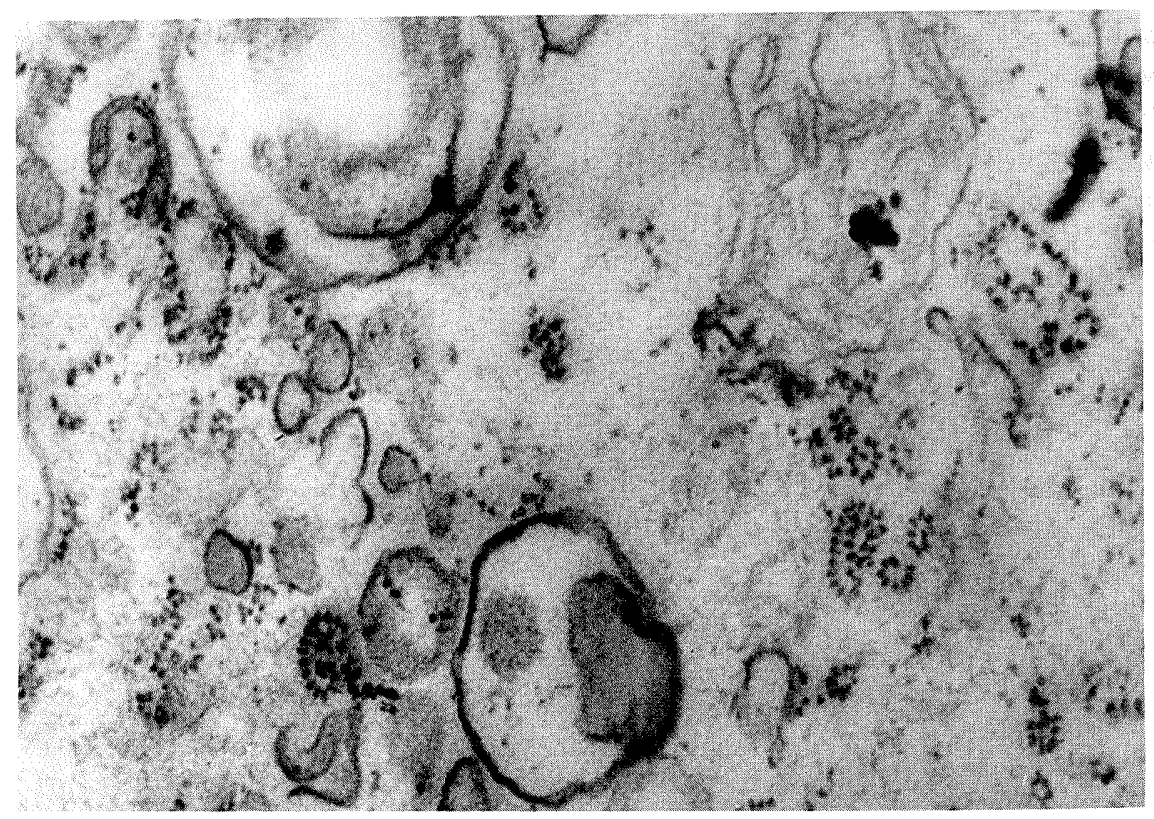

Fig. 1. Contaminated mitochondrial fraction $\times 60000$. The postnuclear supernatant was centrifuged for $15 \mathrm{~min}$ at $15000 \times \mathrm{g}$ and the resulting pellet prepared for electron microscopy. Note the occurrence of large polyribsomes. 


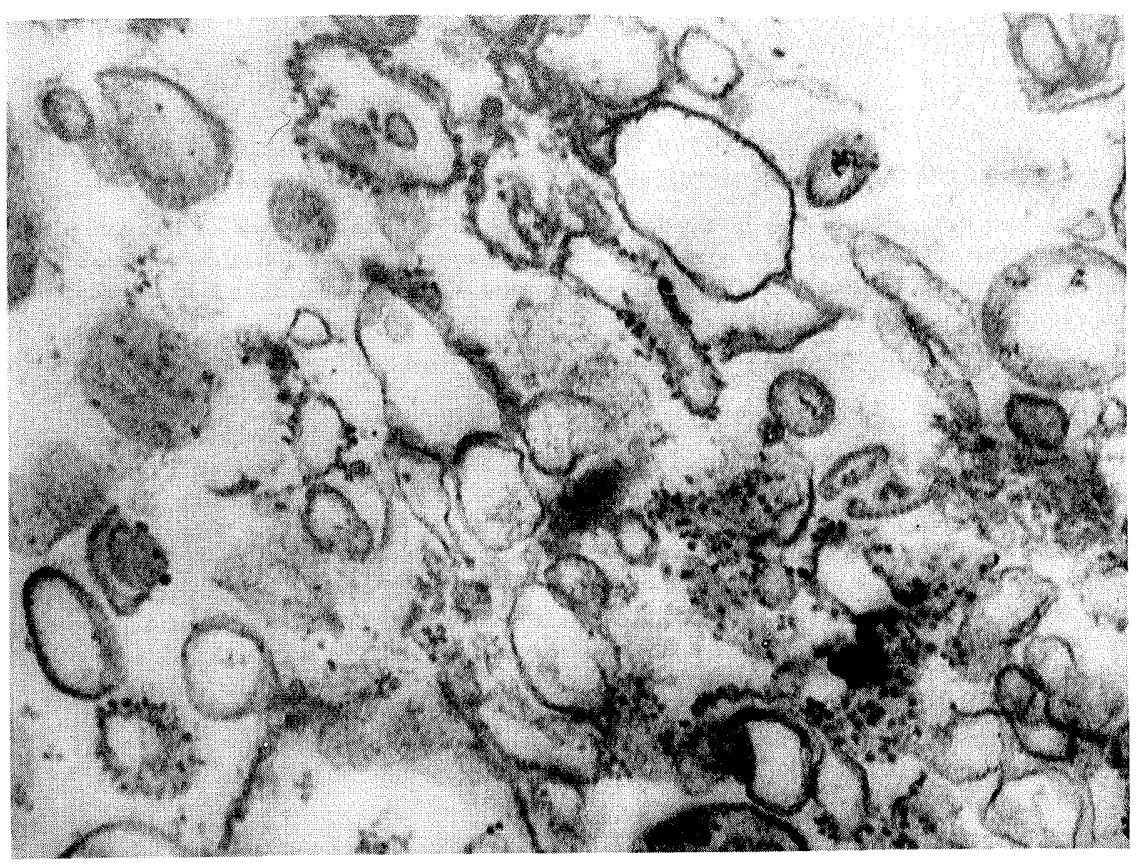

Fig. 2. Washed microsomes (fragmented endoplasmatic reticulum) $\times 60000$. The postmitochondrial supernatant, after centrifugation for $15 \mathrm{~min}$ at $10000 \times \mathrm{g}$, was layered onto a discontinuous sucrose gradient $4 \mathrm{ml} 1.4 \mathrm{M}$ over $4 \mathrm{ml} 2 \mathrm{M}$ sucrose in Tris- $\mathrm{KCl}-5 \mathrm{mM} \mathrm{MgCl} 2$ buffer and centrifuged for $17 \mathrm{~h}$ at $105000 \times \mathrm{g}$. The membranous material (microsomes) at the interphase of $2 \mathrm{M}-1.4 \mathrm{M}$ sucrose was sedimented, washed and prepared for electron microscopy.
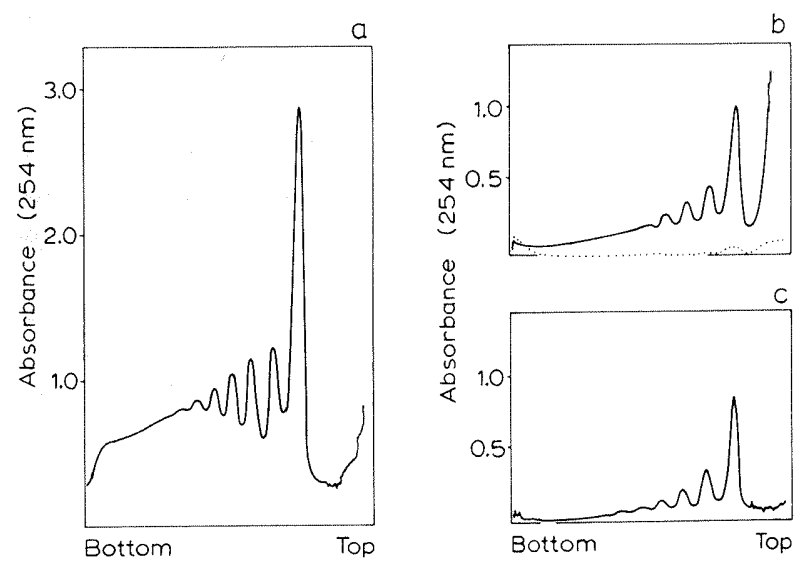

Fig. 3. Sedimentation patterns of free and membrane-bound polyribosomes. (a) Free ribosomes. (b) Membrane-bound ribosomes; ......., control (contaminating free ribosomes). (c) Purified membrane-bound ribosomes. $7 \mathrm{~g}$ of hypocotyl segments were ground in $20 \mathrm{ml}$ of buffer $(0.25 \mathrm{M}$ sucrose, $0.1 \mathrm{M}$ Tris- $\mathrm{HCl}, \mathrm{pH} 8.0,50 \mathrm{mM} \mathrm{KCl}$, and $5 \mathrm{mM} \mathrm{MgCl}_{2}$ ). The postmitochondrial supernatant after centrifugation at $10000 \times$ for $15 \mathrm{~min}$ was layered onto a discontinuous sucrose gradient with $4 \mathrm{ml} 1.4 \mathrm{M}$ over 4 $\mathrm{ml} 2 \mathrm{M}$ sucrose in Tris- $\mathrm{KCl}-5 \mathrm{mM} \mathrm{MgCl}_{2}$ buffer and centrifuged at $105000 \times \mathrm{g}$ for $17 \mathrm{~h}$. The resulting $\mathrm{ml} 2 \mathrm{M}$ sucrose in Tris- $\mathrm{KCl}-5 \mathrm{mM}$ somes were prepared from the microsomes collected above the $2 \mathrm{M}$ sucrose layer. Microsomes were somes washed and treated with Triton X-100 (in the control with branous material at $10000 \times \mathrm{g}$ for $15 \mathrm{~min}$ the supernatants contained the membrane-bound ribosomes (with Triton X-100) or contaminating free ribosomes (without Triton X-100). Purified membrane-bound (with Triton $\mathrm{X}-100$ ) or contaminating free ribosomes (witon X-100 mixture onto a discontinuous sucrose gradient as mentioned above, and it was centrifuged for $17 \mathrm{~h}$ at $105000 \times \mathrm{g}$. The pellet was resuspended in Tris- $\mathrm{KCl}-2 \mathrm{mM} \mathrm{MgCl} 2$ buffer and denoted as purified membrane-bound ribosomes. Free and membrane-bound ribosomes were characterized in isokinetic sucrose gradients centrifuged for $3 \mathrm{~h}, 0^{\circ} \mathrm{C}$, at $25000 \mathrm{rev} / \mathrm{min}$ in the SW 25 rotor of a Spinco L 50 centrifuge. 
TABLE I

ULTRAVIOLET-ABSORBANCE AND RELATIVE AMOUNTS OF RIBOSOMES OR RIBOSOMAL ULTRA VIOLET-ABSORANCE AND RELATIV EQUIVALENT TO $7 \mathrm{~g}$ OF BEAN HYPOCOTYLS SUBUNITS RELEASED FROM MICROSOMES EQUIVALENT TO 7 g OF BEAN Experiments were carried out as described in the legends to Figs 3 . The at $260 \mathrm{~nm}$ on representative subunits released from the microsomes were measured by the absorbance at 260 nme relative amounts were calculated from at least two experiments.

\begin{tabular}{llr}
\hline Conditions & A260 $\mathrm{nm}$ & $\%$ \\
\hline Triton X-100 (membrane-bound ribosomes) & 5.2 & 100 \\
Triton X-100 and discontinuous gradient & & \\
(purified membrane-bound ribosomes) & 3.8 & 76 \\
Control (wi thout Triton X-100) & 0.1 & 4 \\
3 mM EDTA & 0.8 & 20 \\
5 mM EDTA & 3.5 & 70 \\
500 m KCl & 0.2 & 5 \\
Puromycin at 50 mM KCl & 1.5 & 74 \\
Puromycin at 500 mM KCl & 3.6 & 10 \\
Ribonuclease incubation for 0.5 min & 0.4 & 12 \\
Ribonuclease incubation for 1 min & 0.5 & 4 \\
Ribonuclease incubation for 5 min & 0.1 &
\end{tabular}

preparation [18]. Purification of membrane-bound ribosomes through a discontinuous $2 \mathrm{M}-1.4 \mathrm{M}$ sucrose gradient gives a reduction of absorbing material in the ribosome and polyribosome region of the gradient of about 20\% (Figs $3 \mathrm{~b}$, and $3 \mathrm{c}$, Table I). Part of this reduction may be due to material which was adsorbed to the ribosomes.

Size distribution of free and membrane-bound polyribosomes were very similar as seen in the gradients (Figs $3 a-3 c$ ). We find about twice as many monomers as dimers. Free and membrane-bound polyribosomes too were not significantly attacked by ribonucleases at $0^{\circ} \mathrm{C}$. No visible change in the polyribosome profile was observed for a preparation standing $24 \mathrm{~h}$ in an ice bath.

To investigate the ribosome-membrane interaction, washed microsomes were treated with EDTA [21] in a wide range of concentrations $(1-40 \mathrm{mM})$, puromycin $[19,25,26]$ at different ionic strength and ribonuclease $[22,23]$. For these experiments, the microsome preparation had to be without contamination of free ribosomes. Therefore microsomes as control were resuspended (see Material and Methods), centrifuged for $30 \mathrm{~min}$ at $10000 \times \mathrm{g}$ and the supernatant layered onto an isokinetic sucrose gradient. As shown in Fig. $3 \mathrm{~b}$ the preparation was nearly free of contaminating or easily detachable ribosomes. To thus washed microsomes EDTA was added and the detached ribosomal subunits were characterized in a linear sucrose gradient. Up to $2 \mathrm{mM}$ EDTA no ultraviolet-absorbing material was released from the microsomes. Moreover at $2 \mathrm{mM}$ EDTA and less the small amount of free ribosomes present as contaminants sedimented with the membrane fraction. A similar aggregating effect has been observed with pancreas [24] and hepatic [21] ribosomes. At 3 $\mathrm{mM}$ EDTA large and small ribosomal subunits are released from the membranes. Up to $5 \mathrm{mM}$ EDTA the gradient shows about $50 \%$ more ultravioletabsorbing material sedimenting in the region of the small ribosomal subunit than in that of the large one (Figs $4 \mathrm{a}$ and $4 \mathrm{~b}$ ). Free ribosomes, dissociated by 5 

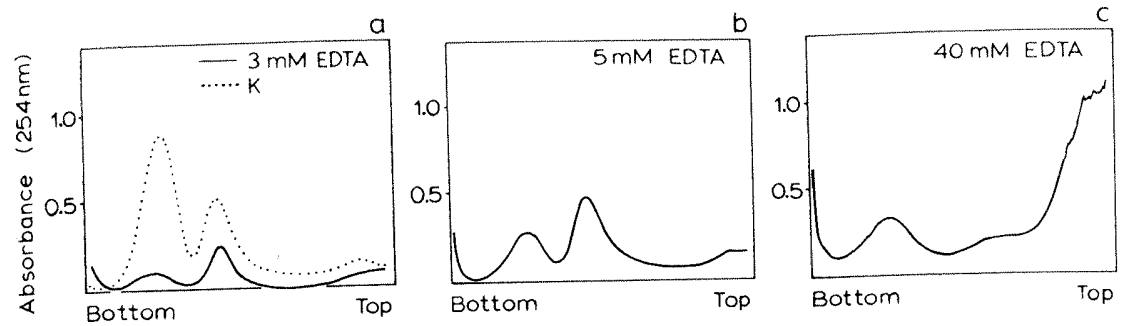

Fig. 4. Sedimentation patterns of subunits from free and membrane-bound ribosomes treated with EDTA. Free ribosomes (5 mM EDTA); — microsomes (3 mM EDTA). (b) Microsomes (5 mM (a) ........ Free ribosomes (5 mM EDTA); - Free ribosomes $(6.0$ A $260 \mathrm{~nm}$ units) resuspended in $1 \mathrm{ml}$ EDTA). (c) Microsomes (40 mM EDTA). Free ribosomes $\left(6.0 A_{2} 60 \mathrm{~nm}\right.$ units) resuspended in 1 m Tris-KCl-2 $\mathrm{mM} \mathrm{MgCl} 2$ buffer were treated with $5 \mathrm{mM}$ EDTA. After incubation for $1 \mathrm{~h}$ at $0 \mathrm{C}$ the Tris-KCl-2 $\mathrm{mM} \mathrm{MgCl}_{2}$ bufore sucrose gradient in $50 \mathrm{mM}$ Tris-HCl, pH 7.8, $40 \mathrm{mM} \mathrm{KCl}$ and mixture was layered onto a 5-20\% linear sucrose gradient in 50 mM Sinco L 50 centrifuge. Microsomes centrifuged for $12 \mathrm{~h}, 2^{\circ} \mathrm{C}$, at $25000 \mathrm{rev}$. $/ \mathrm{min}$ in the SW 25 rotor of a Spinco L 50 centrifuge. Microsomes prepared as described undex Fig. 2 were resuspended in Tris- $\mathrm{KCl}-2 \mathrm{mM} \mathrm{MgCl} 2$ buffer with 3,5 , or $40 \mathrm{mM}$ EDTA in a final volume of $1 \mathrm{ml}$ and incubated for $1 \mathrm{~h}$ at $0^{\circ} \mathrm{C}$. After centrifugation for $30 \mathrm{~min}$ at 10

$X g$ the supernatants were characterized on linear sucrose gradients as EDTA-treated free ribosomes.

mM EDTA give the expected ratio of $2: 1$ for the large to small ribosomal subunit (Fig. 4a).

At EDTA concentrations above $5 \mathrm{mM}$ the peak of the large ribosomal subunit is enlarging while that corresponding to the small one is more and more reduced. At $40 \mathrm{mM}$ EDTA unfolding and disassembly of the subunits especially of the small ones become visible (Fig. 4c).

It is known, that ribosomes without nascent polypeptide chain dissociate into their subunits in the presence of $\mathrm{MgCl}_{2}$ and $500 \mathrm{mM} \mathrm{KCl}$ whereas ribosomes with nascent chains do not dissociate under these conditions except the chains have been released by puromycin $[25,26]$.

Therefore it should be possible to estimate the proportion of membranebound ribosomes with nascent chains by inducing dissociation and to show whether ionic interaction and/or nascent chains are involved in the ribosome membrane attachment $[11,19]$.

Washed microsomes were treated with $\mathrm{KCl}$ at low $(50 \mathrm{mM})$ or high $(500$

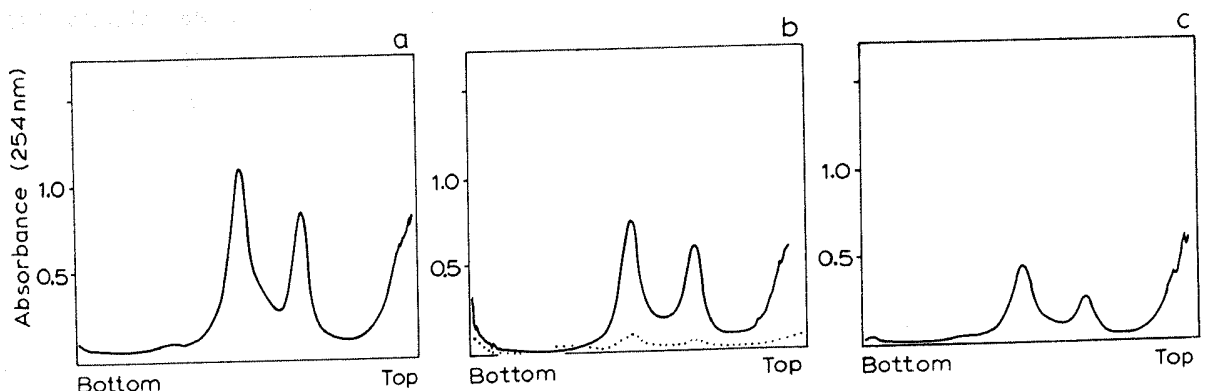
Fig. 5. Sedimentation patterns of subunits from free polyribosomes and membos $\left(5.0 A_{260} \mathrm{~nm}\right.$ units, $0.5 \mathrm{mM}$ treated with puromycin at 50 and $500 \mathrm{mM} \mathrm{KCl}$. (a) Free polyriosom puromycin, $500 \mathrm{mM} \mathrm{KCL})$. (b) - Microsomes ( $0.5 \mathrm{mM}$ puromy cin, $500 \mathrm{mM}$. The incubations were performed somes ( $500 \mathrm{mM} \mathrm{KC1).} \mathrm{(c)} \mathrm{Microsomes}(0.5 \mathrm{mM}$ puromycin, $50 \mathrm{mM} \mathrm{KCl}$ ). The incubations whe sample in $50 \mathrm{mM}$ Tris- $\mathrm{HCl}, \mathrm{pH} 7.8,2 \mathrm{mM} \mathrm{MgCl} 2$ in a final volume of $1 \mathrm{ml}$. without puromycin was treated at $0^{\circ} \mathrm{C}$. After $10 \mathrm{~min}$ standing in an ice bath the mixturese gradients in fuged for $30 \mathrm{~min}$ at $10000 \times \mathrm{g}$ and the supernatants layered onto isokinetic sucrose gradients Tris- $\mathrm{KCl}-2 \mathrm{mM} \mathrm{MgCl}$ buffer. The gradients were centrifuged for $12 \mathrm{~h}, 2 \mathrm{C}$ at 25 SW 25 rotor of a Spinco $\mathrm{L} 50$ centrifuge. 


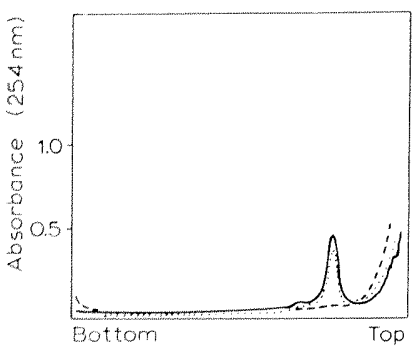

Fig. 6. Sedimentation patterns of ribosomes derived from ribonuclease-treated microsomes. Microsomes, resuspended in Tris $-\mathrm{KCl}-2 \mathrm{mM} \mathrm{MgCl} 2$ buffer were incubated with $10 \mu \mathrm{g}$ of pancreatic ribonuclease in a final volume of $1 \mathrm{ml}$ for: $\ldots \ldots, 0.5 \mathrm{~min} ; \ldots, 1 \mathrm{~min} ; \ldots . ., 5 \mathrm{~min} ;$ at $37^{\circ} \mathrm{C}$. After cooling the mixtures were layered on isokinetic sucrose gradients in Tris- $\mathrm{KCl}-2 \mathrm{mM} \mathrm{MgCl} 2$ buffer and centrifuged for $3 \mathrm{~h}, 0^{\circ} \mathrm{C}$, at $25000 \mathrm{rev} . / \mathrm{min}$ in the SW 25 rotor of a Spinco L 50 centrifuge.

$\mathrm{mM}$ ) concentrations in the presence or absence of puromycin (Figs $5 \mathrm{~b}$ and $5 \mathrm{c}$ ). Maximal release of ribosomal subunits from membranes required both, puromycin and high $\mathrm{KCl}$ concentration (Fig. $5 \mathrm{~b}$ ). Low and high salt concentrations alone remove less than $10 \%$ (Table I), whereas low salt concentration with puromycin releases about $30-40 \%$ of the membrane-bound ribosomes (Fig. 5c, Table I). Mild digestion of washed microsomes for 0.5 and 1 min with $10 \mu \mathrm{g}$ ribonuclease $/ \mathrm{ml}$ at $37^{\circ} \mathrm{C}$ effects the release of about $10 \%$ of the membranebound ribosomes (Fig. 6, Table I). Incubations for 0.5 and 1 min show similar profiles, whereas a prolonged incubation resulted in degradation of the monosomes.

\section{Discussion}

The association of ribosomes and membranes has been characterized for mammalian cells, but very little is known as yet about the attachment of plant ribosomes to membranes $[2,3]$. This communication reports the isolation and characterization of membrane-bound ribosomes from bean stem tissue.

Our microsome preparation shows about $20 \%$ of the ribosomes bound to membranes. Reports on microsomes from mammalian cells demonstrated that a considerable amount of polyribosomes and cytoplasmic membranes contaminates the nuclear and mitochondrial fraction. By chosing low centrifugation forces for sedimentation of mitochondria we tried to reduce the loss of free and membrane-bound ribosomes. Nevertheless the portion of membrane-bound ribosomes in vivo might be considerably larger [3]. We have to consider that very large fragments of the endoplasmic reticulum of remnants which have not been stripped off from the nuclear membranes may contaminate the nuclear and mitochondrial fraction [3].

An absorbance ratio of $2: 1$ of the large to the small ribosomal subunit would be expected if the whole ribosomes were to become detached upon the addition of EDTA and then dissociated into the subunits or if the process of dissociation and detachment was simultaneous [21] (Fig. 4a). Treating microsomes with EDTA concentrations between 3 and $5 \mathrm{mM}$ the small ribosomal subunit could be recovered from the supernatant (see Material and Methods) to a much higher extent than the large one (Figs $4 \mathrm{a}$ and $4 \mathrm{~b}$ ). 
This result indicates that a certain portion of ribosomes is bound to membranes via their large subunit and that this ribosome membrane interaction is independent of $\mathrm{Mg}^{2+}$. Similar results have been reported for mammalian cells [21].

About $10 \%$ of the membrane-bound ribosomes were released by high $\mathrm{KCl}$ concentration alone. It has been suggested, that the $\mathrm{KCl}$-sensitive link is a direct electrostatic bond between ribosome and membrane [19]. Thus in our preparation only few ribosomes seem to be linked by electrostatic binding alone (released by high $\mathrm{KCl}$ ) but about $30 \%$ are linked to the membrane by the nascent peptide chain alone (released by puromycin at low $\mathrm{KCl}$ concentration). There are about $70-80 \%$ of the ribosomes which are detached from the membranes by puromycin together with high salt concentration. Puromycin at $500 \mathrm{mM}$ $\mathrm{KCl}$ released about twice as much ribosomes as $50 \mathrm{mM} \mathrm{KCl}$ and puromycin applied separately. This means that a considerable part of the ribosomes may be linked to membranes by both the nascent peptide chain and electrostatic bond [19]. We conclude therefore that proteins synthesized on membranebound ribosomes become incorporated into the membrane or are secreted into the intracisternal spaces.

Mild ribonuclease digestion of microsomes detaches only a very small portion of ribosomes from the membrane. This result makes it very unlikely that mRNA is responsible for a specific attachment of ribosomes to membranes. In tissue culture cells ribosomes may be bound to the membranes by virtue of their attachment to mRNA $[22,23,28]$. In cells that mainly synthesize proteins for secretion, for example rat liver cells, ribosomes bind to the membrane by the growing peptide chain [19]. Membrane attachment in growing plant tissue resembles more the type of attachment found in rat liver cells than that of tissue culture cells. For growing plant cells we have to consider, that proteins have to be excreted via the Golgi complex where most of the cell wall substances are performed [29]. This leads us to speculate that in growing plant stem tissue proteins synthesized on membrane-bound polyribosomes are preferentially engaged in cell wall metabolism. These proteins might be transported from the rough endoplasmic reticulum via the agranular endoplasmic reticulum to the Golgi complex and for some proteins at least further into the cell wall. This functional aspect is currently under study.

\section{Acknowledgement}

This work has been supported by the Deutsche Forschungsgemeinschaft.

\section{References}

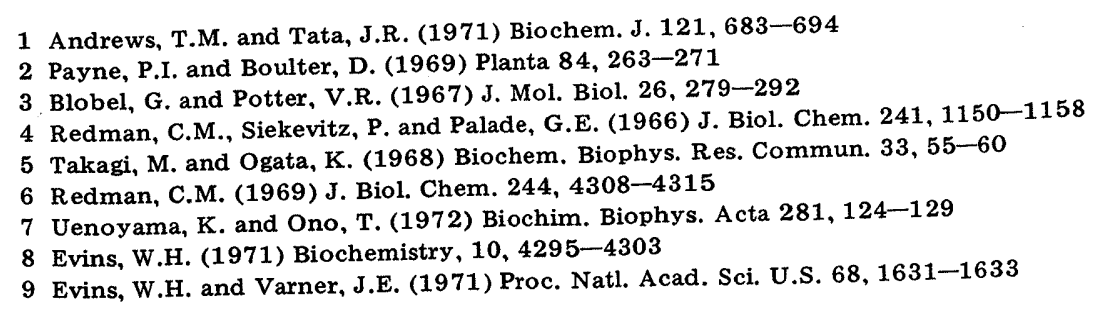


10 Omura, T and Kuriyama, Y. (1971) J. Biochem. Tokyo 69,651-657

11 Chura, N., Blobel, G., Siekevitz, P. and Palade, G.E. (1973) Proc. Natl. Acad. Sci. U.S. 70, 1554-1558

11 Chua, N., Blobel, G., Siekevitz, P. and Pa

13 Tate, J.R. (1968) Nature 219, 331-337

14 Larkins, B.A. and Davies, E. (1973) Plant Physiol. 52, 655-659

14 Larkins, B.A. and Davies, E. (1973) P. (1969) Arch. Biochem. Biophys. 129, 581-587

15 Davies, E. and MacLachlan, G.A. (1969) Arch. B. D.J. (1972) Biochem. Biophys. Res. Commun. 46, $245-253$

17 Noll, H. (1967) Nature 215, 360-363

18 Noll, H. (1969) Techniques in Protein Biosynthesis (Campbell, P.N. and Sargent, J.R., eds), Vol.2, pp. 101-179, Academic Press, London

(1973) J. Cell. Biol. 56, 206-229

20 Franke, W.W., Krien, S. and Brown, Jr, R.M. (1969) Histochemie 19, 162-164

20 Franke, W. W. Tashiro, Y. and Palade, G.E. (1966) J. Mol. Biol. 19, 503-524

21 Sabatani, D.D., Tashiro, Y. and Palade, G.E. (19. Schwartz, J. and Kaighn, M.E. (1973) Biochim. Biophys. Acta 312 ,$$
\text { 492-501 }
$$

23 Rosbash, M. and Penman, S. (1971) J. Mol. Biol. 59, 227-241

24 Madison, J.T. and Dickman, S.R. (1963) Biochemistry 2, 321-326

25 Blobel, G. and Sabatani, D. (1971) Proc. Natl. Acad. Sci. U.S. 68, 390-394

25 Blobel, . and (1973) Proc. Natl. Acad. Sci. U.S. 70, 3866-3869

26 Azzam, M.E. and Algranati, I.D. (1973) Proc. Natl. Acad. Scl. U.S. 70, 3866-1069-1074

27 Tanaka, T. and Ogata, K. (1972) Biochem. Biophys. Res. Com Biol. 49, 683-691

28 Thiman, K.V. (1972) Plant Physiology (Steward, F.C., ed.), Vol. VIB, pp. 237-250, Academic Press, New York 